\title{
Book Review Classic Hikes of the World
}

\author{
Classic Hikes of the World by Peter Potterfield \\ New York, W. W. Norton \& Co., 2005 \\ 224, pp., US\$ 39.95 (hardcover) \\ ISBN 9780393057966
}

Seattle-based Peter Potterfield is a highly acclaimed award-winning writer with a passion for adventure travel. His highly acclaimed works have been published in many magazines such as the National Geographic Adventure, the Conde Nast Traveler, Outside, Backpacker and the Reader's Digest. He is also the author of High Himalaya and In the Zone, among other books.

In his most recent book Classic Hikes of the World; he covers the world's best hiking routes across seven continents, making this a bible for intrepid trekkers. In order to maximize hiking trip, Potterfield has rounded up 23 classic itineraries (adrenaline outposts). As the author himself hails from North America, he has obviously devoted most of his energy in highlighting 11 classical hikes of North America while rest of the continents are given their share of two to three classical hikes each. Each chapter contains invaluable advice, both for novices and seasonal trekkers, including level of difficulty, both in physical effort and psychological challenge; details on trail conditions and recommended seasons; notes on potential hazards or difficulties; detailed route descriptions; maps of all hiking routes; and resources for information, staging, accommodation and transportation.

The collection spans the whole world and the author in his choices has tried his best to be comprehensive. From the great Himalayan peaks of Nepal to the lush green hills of New Zealand, hiking is becoming popular, and the book has made an attempt to document a vast array of choices that are available. Hiking amidst different cultures, different natural and environmental settings and different degrees of difficulties requires sound planning and loads of information to choose the right combination before setting out for hiking. This book really scores well in this particular area.

This adrenaline-soaked book introduces Dingboche, a sleepy hamlet on the way to the Everest Base Camp, where the author himself is disarmed by the landscape 
and lost in the wilderness that reminds him of his professed goal: "to spend time in the places that remain wild, to see the beauty of the world". The introduction chapter dwells on structure and on how to use the book. Each hiking chapter begins with pertinent information noting the particular route's appeal and unique features, along with some historical notes. However, Potterfield recommends that the best way to use the book is for the readers themselves to go on those hikes. In order to have experience of these trekking routes, the author has a simple advice: Dream it, plan it, just do it!

Under the North America section, Potterfield lucidly and succinctly explains the John Muir Trail (Southern California, USA), a trail which every trekker dreams of traversing someday, akin to the Annapurna Circuit of Nepal. The trail officially runs for $354 \mathrm{~km}$ from the summit of Mt. Whitney to Happy Isles in the Yosemite Valley. It takes between 18-24 days to cover the trail. The author also provides information on how to replenish food along the route by providing names of resupply points along the trail.

The jewel in the crown of hiking is none other than hiking in the Antarctic region - the Shackleton Crossing. In fact, it is one of the most gripping survival stories where Shackleton made an ambitious plan to cross Antarctica but his ship sank on the way and both Shackleton and his team members struggled to survive after being left adrift on a frozen sea for 18 whole months. Nonetheless, this remains an undiscovered gem.

Equally stunning is the Routeburn Track in New Zealand, a country known as an adventure enthusiast's dreamland. The Routeburn Track is for those who love to explore and enjoy natural wilderness. The track is one of the Great Walks of New Zealand, a collective name given to the country's eight premier walking tracks and one river journey. The track takes four days to complete traversing along the flank of the Ailsa Mountains, the southwestern corner of New Zealand's Southern Alps, taking in scenic splendors where one can explore two of the country's largest national parks - Fiordland and Mt. Aspiring - in the heart of a World Heritage Area.

Nepal, known as a hiker's paradise, where there is an extensive range of treks to choose from, has been well-documented in this book: the Everest Base Camp (EBC) and the Royal Trek. The EBC is known as the most popular trekking route besides the Annapurna Circuit. Although the author warns of high climb resulting in altitude sickness, he is quick to add that the trek has many intangible rewards: spectacular natural beauty and rich cultural experiences of the Sherpa people. Among adventure-hiking aficionados, EBC is one of the most talked about hikes in the world. For those who really want to be lost in the natural splendor and physical beauty of Everest, the EBC trek can become an experience of a lifetime. The jewel in the crown is the majestic view of Everest. Compared to the EBC, the Royal Trek is a soft trek. Those who enjoy a laid-back lifestyle attitude are 
surely going to enjoy this hiking. The crowning glory of the Royal Trek is that it is a low-level trekking with easy-going people from picturesque villages of Gurung, Chhetri and Newar communities. The trek can be enjoyed during fall, winter or spring but not during monsoon. While trekking in Nepal there is always a reward in the form of a sense of achievement and closeness with the nature. Overall, Nepal offers a warm welcome to visitors, a good place to bunk where one can mix at ease with the locals.

Those who have been to Nepal would be shocked to find the Annapurna Circuit, regarded as one of the world's best trekking routes, missing from the book. Another big surprise is to see soft treks such as the Royal Trek being billed as classic hikes. The Everest Base Camp is explained in a very clear manner. However, one thing the author has surprisingly failed to mention in the chapter is the iconic monument of the EBC - Tangboche Monastery.

Peter Potterfield is a leading authority on the subject of trekking. He could have done more justice to the book had there been mention of Bhutan's Snowman trekking - considered one of the hardest treks in the world lasting around 24 days and having altogether 11 passes. The book also disappoints with its use of ordinary photographs.

For people who really love trekking and are intrepid adventurers, this is armchair reading at its best. The book appeals to anyone with a healthy dose of adventure. The book is a treasure trove for adventure enthusiasts and offers an unforgettable lifetime escape into the wilderness.

Reviewed by: Sunil Sharma ssharma@ntb.org.np 